\title{
Malacofauna of Holocene freshwater calcareous deposits of Lithuania
}

\author{
Aleksander Sanko, \\ Julius Vainorius, \\ Monika Melešytè
}

Sanko A., Vainorius J., Melesyte M. Malacofauna of Holocene freshwater calcareous deposits in Lithuania. Geologija. Vilnius. 2010. Vol. 52. No. 1-4(69-72). P. 16-24. ISSN 1392-110X

The malacofauna of freshwater calcareous deposits of Lithuania was studied. Sections of the Mūšos Tyrelis and Pabaliai peatbogs near the town of Šiauliai, as well as Dubičiai section (three sites) in SE Lithuania and Dūkštos in Central Lithuania were investigated. Freshwater calcareous deposits are attributed to three groups of facies - lacustrine, valley-hollow-peatbog and terrestrial. Each group of facies consists of sub-facies (freshwater lime, "gazha" (limno-calcite), peattufa, calcareous tufa, "mada") varying the formation conditions, composition and other characteristics. The mollusc fauna in the lacustrine facies group (Mūšos Tyrelis and Pabaliai sections) is represented by lacustrine species containing euryecological freshwater molluscs. Terrestrial and rheophilous species are rare or absent in the lacustrine group. Deposits of valley-hollow-peatbog facies contain shells of euryecological freshwater and lacustrine molluscs together with rheophyl shells, sometimes with abundant terrestrial shells, as was observed in the Dubičiai-4 section. A characteristic feature of the terrestrial facies group deposits is the occurrence of solely terrestrial mollusc shells (Dūkštos section).

Key words: malacofauna, freshwater calcareous deposits, Holocene, Lithuania

Received 23 October 2010, accepted 08 November 2010

Aleksander Sanko. Belarusian State Pedagogical University, Sovetskaya St. 18, 220030 Minsk, Belarus.E-mail: sankoaf@tut.by.Julius Vainorius. Institute of Geology and Geography, T. Ševčenkos 13 , LT-03223 Vilnius, Lithuania. E-mail: juliusvainorius@yahoo.com. Monika Melešytė. Department of Geology and Mineralogy, Vilnius University, M. K. Čiurlionio 21/27, LT-03101 Vilnius, Lithuania.E-mail: monika.melesyte@gf.vu.lt

\section{INTRODUCTION}

Freshwater calcareous Holocene deposits are common in Lithuania (Barto , 1976). They crop out on the slopes of ravines, river terraces, as well as on the bottom of lakes, bogs (under peat beds) and lagoons of the Baltic Sea. They were accumulated by outflows of groundwater rich in calcium carbonate. The genetic facies of freshwater calcareous deposits comprise those of sources (springs) on the slopes of different type, freshwater beds on lake bottoms, carbonate accumulations in bogs due to confined water rise (springs), as well as those in river valleys, mainly at the sites of oxbow lakes. Deposits of spring origin (calcareous tufa) are mainly of a grainy, tight, porous and lumpy structure. Lake-bog and alluvial deposits are notable for loose, fine-grained and pelitomorphous calcareous deposits with the size of particles, according to I. J. Danilans (Danilans, 1957), not exceeding $0.2 \mathrm{~mm}$.
Holocene freshwater calcareous deposits are considered as a useful mineral occurring at shallow depths or cropping out at the surface and being long used for improving soils by calcification. These deposits also present an important source of palaeontological data, especially on malacofauna, enabling to reconstruct the conditions and peculiarities of their formation.

The Holocene freshwater calcareous deposits are scarcely studied in terms of malacofauna in Lithuania. Some facies still lack characterisation with regard to malacofauna. Quite recently, the malacofauna characterisation of calcareous tufa has been performed in Lithuania for the first time (Sanko et al., 2008). The Holocene and Late Glacial lacustrine and alluvial malacofauna has been studied in some cases (Vaitekūnas ir kt., 1970; Gaigalas et al., 2007; Sanko, Gaigalas, 2008). The freshwater and marine malacofauna of the Baltic Sea coast has been investigated in more detail (Damušytè, 2009). 


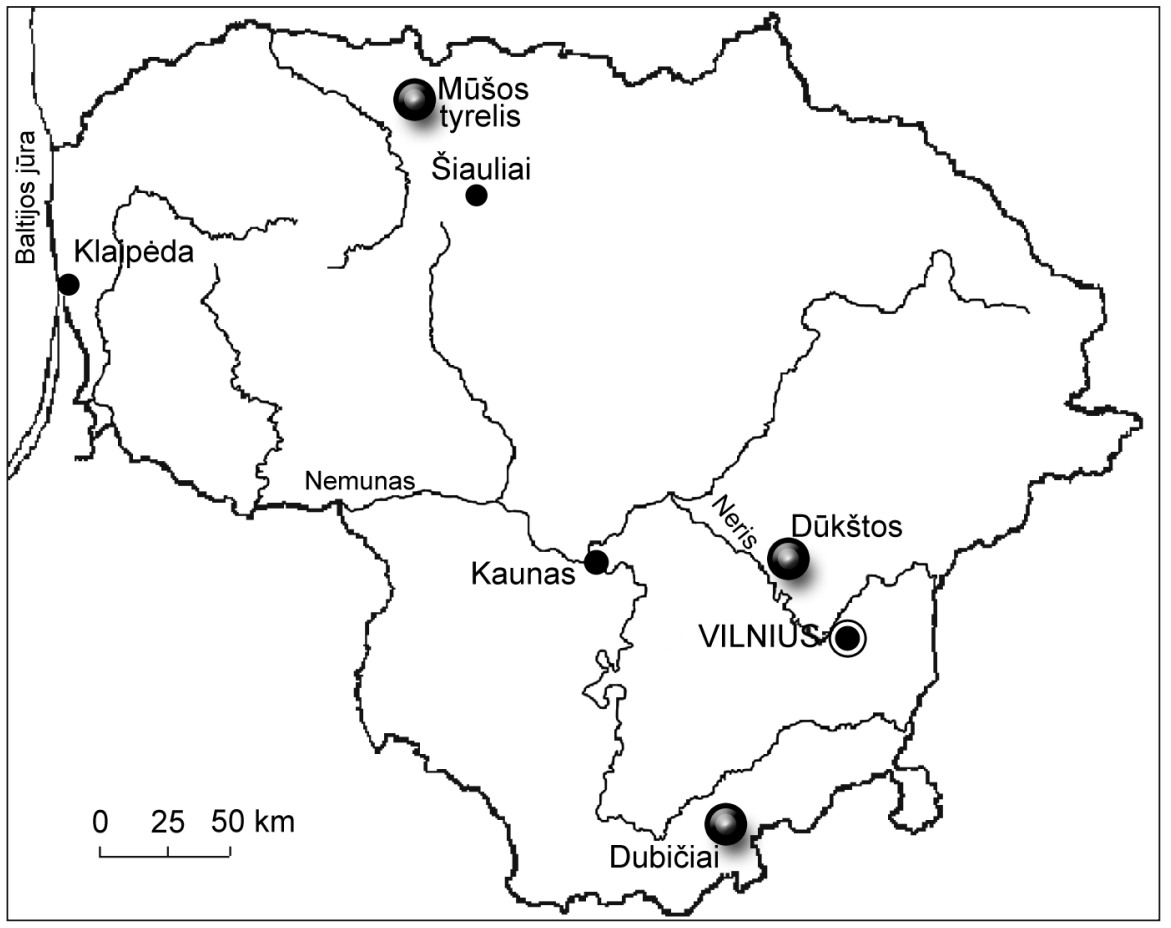

Fig. 1. Location of sections studied 1 pav. Nuogulų tyrimo vietos
We report data on the composition, formation peculiarities, type of facies and, in some cases, age of fossil mollusc associations, as determined in four sites of freshwater calcareous deposits in Lithuania: Mūšos Tyrelis, Pabaliai, Dubičiai and Dūkštos (Fig. 1).

\section{RESULTS}

\section{Mūšos Tyrelis malacofauna}

The Mūšos Tyrelis peatbog is situated in Joniškis District, about $30 \mathrm{~km}$ west of the Joniškis town, in a watershed bog of the Venta Plain representing part of the Middle Venta River physical-geographical region. Deposits of the Mūšos Tyrelis peatbog were

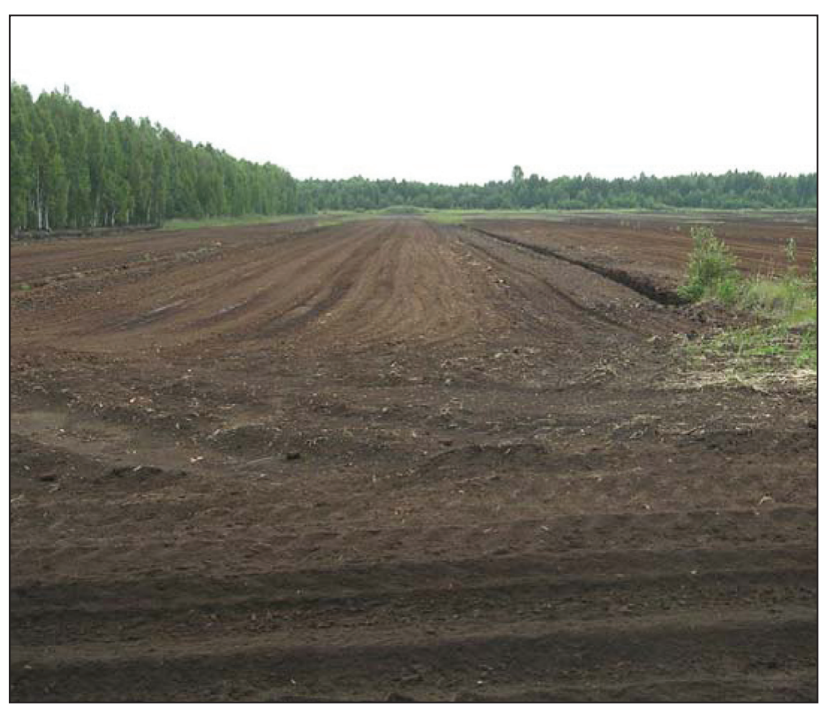

Fig. 2. Mūšos Tyrelis peatbog

2 pav. Mūšos tyrelio durpynas formed in the lake / bog environment of a remnant glaciolacustrine basin. With the glacier retreating and climate warming, the bogging of this shallow basin progressed rapidly. The bogging was favoured by the newly formed Mūša and Švetė rivers. The lacustrine deposits as thick as 1 to $2 \mathrm{~m}$ are overlain by a peat bed reaching $9 \mathrm{~m}$ in thickness in some places. By present, about half of the peat deposit is exhausted by intense exploitation (Fig. 2). The peat thickness is about $1.5 \mathrm{~m}$ in the excavation site (the upper part of the peat is removed).

Mollusc remains for malacofauna studies were washed from gyttja and sapropel samples taken at 9 levels from silt (1-5 samples), sapropel and gyttja (6-8 samples) and peat (9 samples) beds at 10-cm intervals (Fig. 3 ).

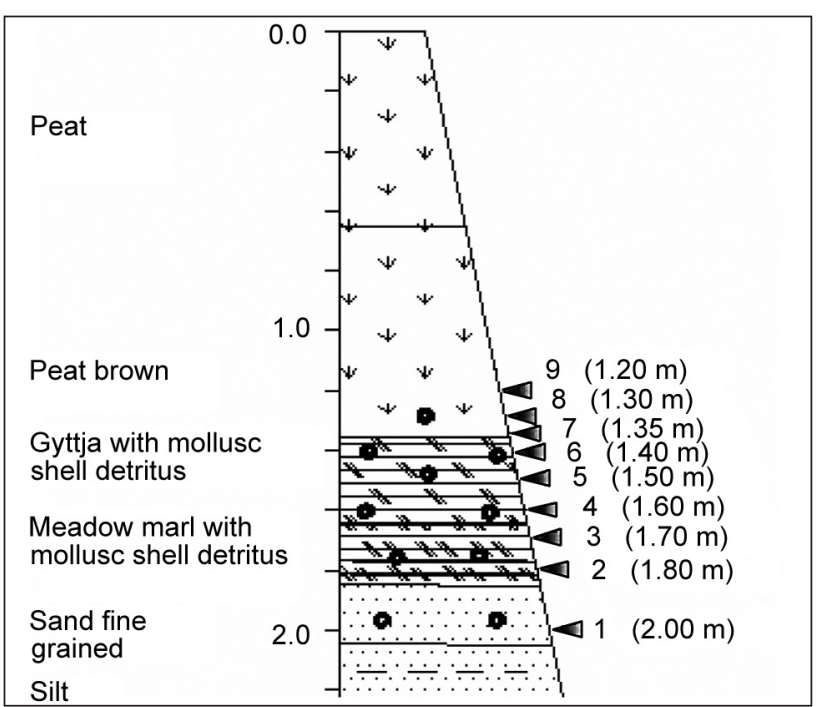

Fig. 3. Section of Mūšos Tyrelis peatbog and mollusc sampling sites 3 pav. Mūšos tyrelio pjūvis ir moliuskų faunos méginių paėmimo vietos 
Nine samples were found to contain large quantities (9310) of molluscs; however, their taxonomic variety was low (Table 1), with 21 taxa (1 terrestrial and 20 freshwater species) defined. Among the freshwater taxa, the euryecological species were rather abundant, e. g., Pisidium milium Held, Pisidium cf. casertanum (Poli), Pisidium nitidum Jenyns. They are adapted to live in any water basins. The number of their specimen prevails over other species in malacofauna. Group 2 comprised representatives of shallow water bodies adapted to populate puddles, pools in meadows and peatbogs and other small water bodies. Lymnaea peregra (Müller) is a characteristic species of small water bodies (Fig. 4). It can be amphibiotic and survive extreme changes of water temperature and $\mathrm{pH}$. Species populating lakes and other stable water bodies of different size make

Table 1. Malacofauna from Late Glacial and Holocene deposits in Mūšos Tyrelis section

1 lentelè. Mūšos tyrelio vèlyvojo ledynmečio-holoceno malakofauna

\begin{tabular}{|c|c|c|c|c|c|c|c|c|c|c|}
\hline $\mathbf{E}$ & Taxon/Samples & 1 & 2 & 3 & 4 & 5 & 6 & 7 & 8 & 9 \\
\hline 9 & Succinea putris (Linnaeus) & & & 1 & & & & & & \\
\hline 10 & Valvata cristata Müller & 1 & & 1 & & & 5 & 70 & 40 & 45 \\
\hline 10 & Bithynia leachi (Sheppard) & & & & & & 1 & 6 & 140 & 28 \\
\hline 10 & Lymnaea truncatula (Müller) & 1 & & & & & & & & \\
\hline 10 & L.peregra (Müller) & 10 & 11 & 11 & 18 & 4 & 45 & 193 & 758 & 218 \\
\hline 10 & Gyraulus rossmaessleri (Auerswald) & & & 1 & 4 & 2 & 4 & & & \\
\hline 10 & Pisidium obtusale (Lamarck) & 10 & 3 & 20 & 10 & 20 & 60 & 138 & 150 & 40 \\
\hline 10 & P. obtusale lapponicum Clessin & 60 & 20 & 75 & 400 & 200 & & & & \\
\hline 11 & Valvata piscinalis alpestris Küster & 2 & & 2 & 5 & 7 & 112 & 137 & 222 & 271 \\
\hline 11 & Bithynia tentaculata (Linnaeus) - shells & & & & & & & & 5 & \\
\hline 11 & Bithynia tentaculata (Linnaeus) - operculatum & & & & & & 1 & 5 & 11 & 5 \\
\hline 11 & Physa fontinalis (Linnaeus) & & & & & & & 3 & 6 & 5 \\
\hline 11 & Lymnaea stagnalis (Linnaeus) & 2 & 11 & 1 & 8 & 13 & 81 & 65 & 54 & 37 \\
\hline 11 & Bathyomphalus contortus (Linnaeus) & & & & & & & 3 & 5 & \\
\hline 11 & Gyraulus laevis (Alder) & 3 & 1 & 2 & 2 & 2 & 10 & & 2 & \\
\hline 11 & Armiger crista Linnaeus & & & & & & 7 & & 1 & \\
\hline 11 & Hippeutis complanatus (Linnaeus) & & & & & & & 1 & 3 & \\
\hline 11 & Sphaerium corneum (Linnaeus) & & & 1 & & & 26 & 15 & 30 & 20 \\
\hline 11 & Pisidium milium Held & 2 & & 3 & 10 & 20 & 130 & 150 & 152 & 250 \\
\hline 11 & P. lilljeborgi Clessin & 10 & & 50 & 200 & 600 & 300 & & & \\
\hline 11 & P. cf. casertanum (Poli) & & 5 & 20 & 100 & 600 & 250 & 200 & & 200 \\
\hline 12 & P. nitidum Jenyns & 10 & 5 & 69 & 80 & 10 & 300 & 700 & 605 & 250 \\
\hline & Total & 111 & 56 & 257 & 837 & 1478 & 1332 & 1686 & 2184 & 1369 \\
\hline
\end{tabular}

E - ecological groups after S. W. Aleksandrowicz (1987) for Tables 1-4.

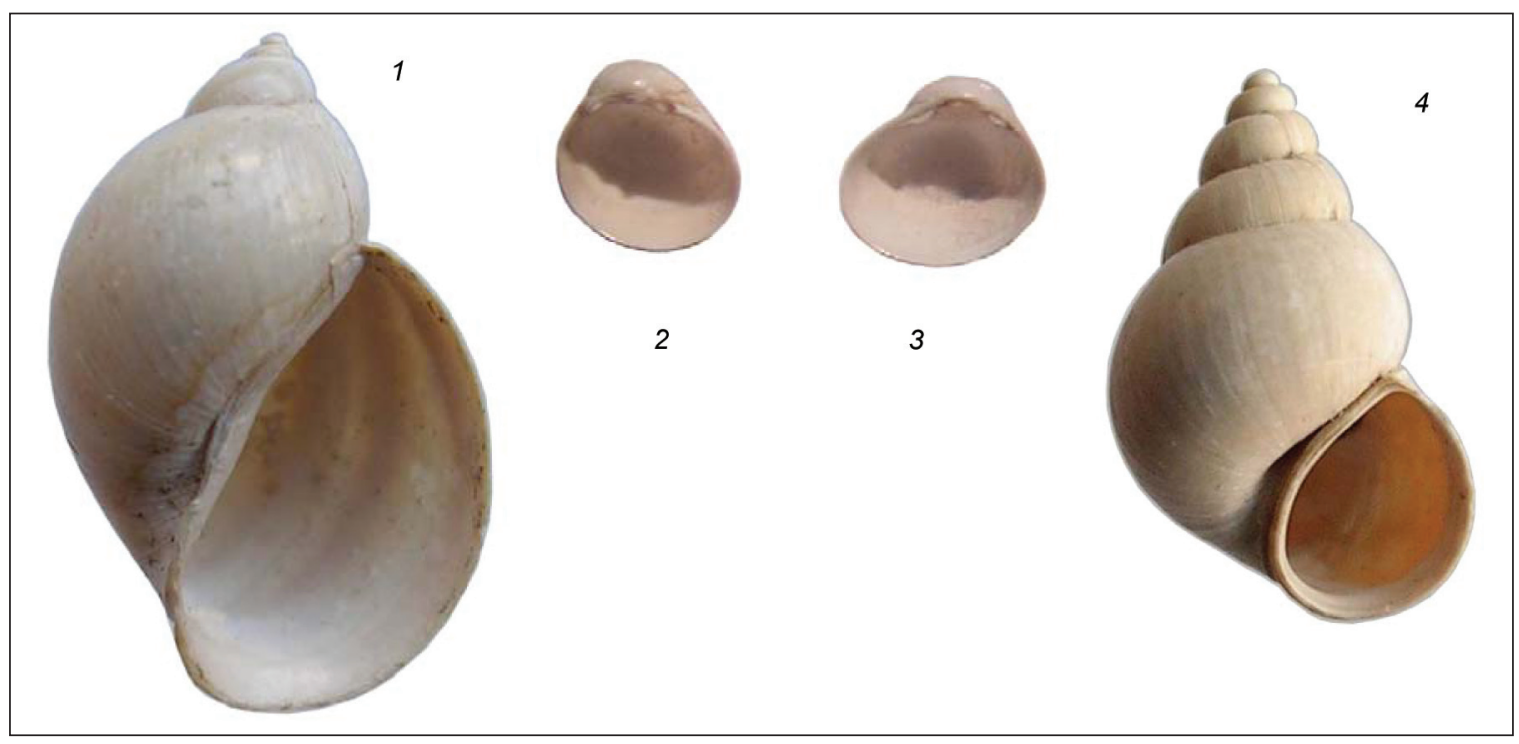

Fig. 4. Mollusc shells from Mūšos Tyrelis section: 1 - Lymnaea peregra (Müller), 2-3-Pisidium obtusale lapponicum Clessin, 4- Bithynia leachi (Sheppard)

4 pav. Moliuskų geldelès iš Mūšos tyrelio pjūvio nuosèdų 


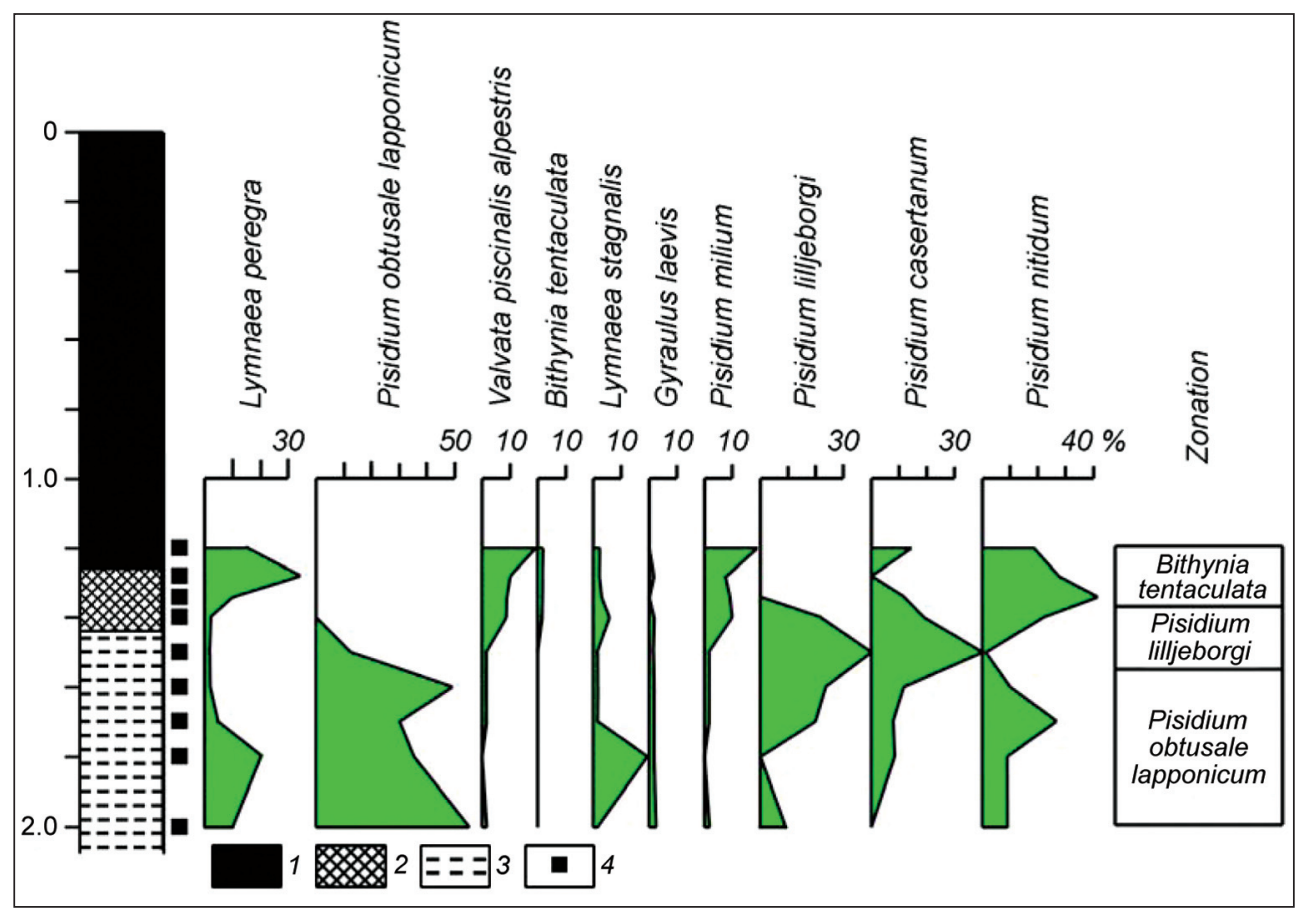

Fig. 5. Malacological diagram of Mūšos Tyrelis section deposits: 1- peat, 2 - gyttja, 3 - lake (meadow) marl, 4- sampling sites 5 pav. Malakologinè diagrama iš Mūšos Tyrelio pjūvio nuosèdų. 1 - durpè, 2 - gitija, 3 - ežerinis mergelis, 4 - mèginių paèmimo vietos

one more ecological group of molluscs in the malacofauna of the Mūšos Tyrelis peatbog. Pisidium lillieborgi Clessin is the most abundant representative in this group.

In the lower part of fauna-rich deposits of Mūšos Tyrelis (samples 1-5) prevail shells of cold-water sub-type Pisidium obtusale lapponicum Clessin (Fig. 4), a typical representative of the Last Glaciation of the Pleistocene and extinct by the Holocene. Thus, based on the last occurence of shells of this type in the section, the boundary between Poozersk (Nemunas) and the Holocene should be defined at the top of the sapropel bed. It is rather well supported by the association of mollusc fauna and its development. Pisidium lilljeborgi Clessin shells are rather characteristic of the periglacial part of the deposits. This is a species of cool water. Although it sometimes occurs in the Holocene of Central and East Europe, it is considered to be a periglacial relict (Piechocki, 1985). The content of shell specimens in fauna-bearing deposits of the section (low at the bottom and high in the upper part) present an additional indicator that this fauna belong to the Late Glacial and the Holocene.

The malacological diagram (Fig. 5) shows that the transition between the Late Glacial and the Holocene malacofaunas coincides with the peak occurrence of P. lilljeborgi Clessin shells. In the lower part of fauna-bearing deposits, prevail shells of P. obtusale lapponicum Clessin - a representative of periglacial period, while shells of Bithynia tentaculata (Linnaeus) appear in the upper part; the latter species is widely spread in Holocene malacofaunas but is absent in Late Glacial faunas in the countries neighbouring to Lithuania. The majority of freshwater fauna species are related to the species transitive from the Late Glacial to the Holocene, Lymnaea peregra (Müller) being a typical species that can dominate both in Late Glacial and Holocene faunas (see Fig. 4).

\section{Pabaliai malacofauna}

The type and time of formation of molluscs of the Pabaliai section (Šiauliai area) are close to those of the Mūšos Tyrelis malacofauna. Their similarity is determined by the occurrence of Arctic and sub-Arctic mollusc Pisidium obtusale lapponicum Clessin, which is observed in association with the periglacial relict P. lilljeborgi Clessin (Table 2). The composition of faunabearing deposits is also rather similar. The malacological diagram (Fig. 6) enables to trace the content and composition of shells in the freshwater deposits. The transition between the shell-bearing and shell-free deposits for periglacial molluscs, mainly P. obtusale lapponicum Clessin, should be marked as the boundary between the Pleistocene and the Holocene, defined between samples 2 and 3. Starting from sample 3, the Holocene species Bithynia tentaculata (Linnaeus) occurs in the deposits, confirming the lower boundary of the Holocene.

\section{Dubičiai malacofauna}

Freshwater calcareous deposits containing mollusc shells are abundant in the flood-plain valleys of the rivers. Malacofauna was studied at three sites situated in the flood-plain of the Pelesa River close to the Dubičiai settlement (SE Lithuania). The Dubičiai 1 site is located on the left bank of the river about $10 \mathrm{~m}$ downstream the bridge. Mollusc shells are detected here in a lens of calcareous gyttja at the depths of 2.4-2.7 m from the flood-plain surface level; the gyttja is overlain by dark brown peat upwards in the section. The alternation of calcareous deposits containing organic remains and peat is called peat-tufa ("mada" in Polish). Their formation is related to the discharge of confined water (springs) at the bottom of bogged rivers and other linear depressions.

The malacofauna of calcareous deposits of the Dubičiai-1 site is attributed to the category of rich faunas. It is 
Table 2. Mollusc fauna in Pabaliai section (Šiauliai)

2 lentelè. Moliuskai iš Pabalių pjūvio (Šiauliai)

\begin{tabular}{|c|c|c|c|c|c|c|c|c|c|}
\hline \multirow{2}{*}{$\mathbf{E}$} & \multirow{2}{*}{ Taxa } & \multicolumn{8}{|c|}{ Sample } \\
\hline & & 1 & 2 & 3 & 4 & 5 & 6 & 7 & 8 \\
\hline 7.14 & Limacidae & & & & 1 & & 1 & & \\
\hline 10.3 & Bithynia leachi (Sheppard) & & & 2 & 3 & 1 & & 25 & 15 \\
\hline 10.8 & Lymnaea peregra (Müller) & 16 & 14 & 12 & 70 & 29 & 120 & 85 & 25 \\
\hline 10.9 & Planorbis planorbis (Linnaeus) & & & & & & 3 & 1 & 10 \\
\hline 10.17 & Pisidium cf. obtusale lapponicum Clessin & 20 & 30 & & & & & & \\
\hline 11.2 & Valvata piscinalis (Müller) & 83 & 140 & 24 & 2 & 5 & 450 & 558 & 400 \\
\hline 11.3 & Bithinia tentaculata (Linnaeus) & & & & & & & & 2 \\
\hline 11.3 & Bithinia tentaculata (Linnaeus) - operculata & & & 3 & 3 & 3 & 6 & 37 & 30 \\
\hline 11.4 & Physa fontinalis (Linnaeus) & & & & & & & 2 & 1 \\
\hline 11.5 & Lymnaea stagnalis (Linnaeus) & & & & & & & & 3 \\
\hline 11.14 & Gyraulus albus (Müller) & & & & & & & 6 & \\
\hline 11.20 & Sphaerium corneum (Linnaeus) & 50 & 125 & & & 1 & & 1 & \\
\hline 11.23 & Pisidium milium Held & 20 & 30 & & & 20 & 15 & 300 & 150 \\
\hline 11.25 & Pisidium lillieborgi Clessin & 50 & 150 & & 1 & & & & \\
\hline 11.27 & Pisidium hibernicum Westerlund & 50 & 150 & & & & & & \\
\hline 12.23 & Pisidium nitidum Jenyns & 100 & 150 & 25 & 15 & 60 & 300 & 600 & 300 \\
\hline & Total & 389 & 789 & 66 & 95 & 119 & 895 & 1615 & 936 \\
\hline
\end{tabular}

Fig. 6. Malacological diagram of Pabaliai section deposits: 1 - peat, 2 - gyttja, 3 - lake (meadow) marl, 4 - sampling sites 6 pav. Malakologine diagrama iš Pabalių pjūvio nuosèdų. 1 - durpè, 2 - gitija, 3 - ežerinis mergelis, 4 - méginių paèmimo vietos

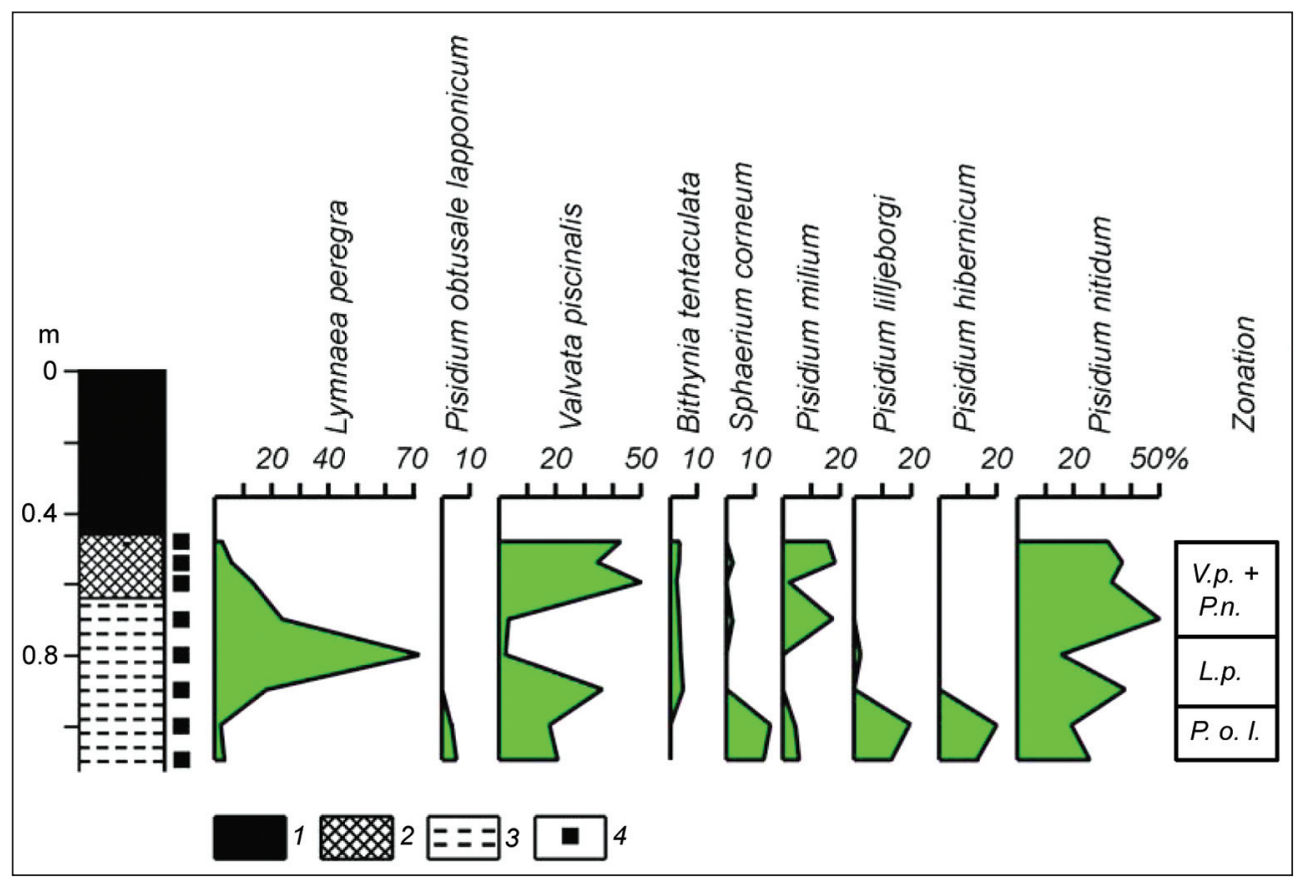

composed of different ecological groups including terrestrial and rheophilous species of 41 taxa (18 terrestrial and 23 freshwater) (Table 3). Occurrence of terrestrial species indicates a proximal position to the slope. The prevalence of species of open spaces and hydrophiles shows that the area was elevated and devoid of arboreal vegetation. Its surface was covered by very wet biotopes; sometimes it was even flooded. The flood-plain seems to have a high topography, but flooded sometimes. The analysis of freshwater mollusc fauna enables to reconstruct the situation when the calcareous deposits were being settled. A rather long and stable outflow of spring water led to the formation of a small overgrowing water body (a large puddle) on the surface of the flood-plain where the settling of lime took place. The water body was populated by aquatic molluscs, which were mainly euryecological species, including such lake molluscs as Viviparus contectus (Millet), Lymnaea stagnalis (Linnaeus) and Acroloxus lacustris (Linnaeus). Their occurrence suggests presence of a water body in the river flood-plain throughout nearly all the year round. During spring floods, the river water was flowing in; this is indicated by occurrence of the river molluscs Pisidium casertanum ponderosa (Stelfox), Ancylus fluviatilis Müller, Unio sp. and Pisidium amnicum (Müller). Rather small occurrence of rheophiles among the freshwater fauna indicates that the flooding events were rare on the flood-plain. 
Table 3. Mollusc fauna in Dubičiai 1 and 4 sections

3 lentelè. Moliuskai iš Dubičių 1 ir Dubičių 4 pjūvių

\begin{tabular}{|c|c|c|c|c|c|c|c|}
\hline \multirow{2}{*}{$\mathbf{E}$} & \multirow{2}{*}{ Taxa } & \multicolumn{3}{|c|}{ Section 1} & \multicolumn{3}{|c|}{ Section 4} \\
\hline & & 1 & 2 & 3 & 1 & 2 & 3 \\
\hline 5.6 & Pupilla muscorum (Linnaeus) & 24 & 28 & 14 & & & \\
\hline 5.8 & Vallonia costata (Müller) & 9 & 21 & 5 & & & \\
\hline 5.9 & Vallonia pulchella (Müller) & 18 & 38 & 34 & & 1 & \\
\hline 7.1 & Cochlicopa lubrica (Müller) & 4 & 17 & 10 & & & \\
\hline 7.3 & Vertigo alpestris Alder & 1 & & & & & \\
\hline 7.7 & Punctum pygmaeum (Draparnaud) & 1 & 1 & & & & \\
\hline 7.9 & Vitrina pellucida (Müller) & 5 & 17 & 2 & & & \\
\hline 7.10. & Nesovitrea hammonis (Strom) & 1 & 2 & & & & \\
\hline 7.15 & Euconulus fulvus (Müller) & 1 & 4 & & & & \\
\hline 7.14 & Limacidae gen. & & 3 & 2 & 1 & 4 & 1 \\
\hline 7.24 & Trichia hispida (Linnaeus) & & & 8 & & & \\
\hline 8.3 & Vertigo angustior (Jeffreus) & 1 & & & & & \\
\hline 9.1 & Carychium minimum Müller & 12 & 10 & 2 & 1 & 1 & \\
\hline 9.3 & Vertigo antivertigo (Draparnaud) & 1 & & & & & \\
\hline 9.9 & Succinea putris (Linnaeus) & 3 & 36 & 13 & & & \\
\hline 9.10 & Succinea elegans (Risso) & 4 & 2 & & 1 & 1 & \\
\hline 9.11 & Zonitoides nitidus (Müller) & & 13 & 11 & & & \\
\hline 9.12 & Monachoides rubiginosa (Schmidt) & 4 & 9 & & & & \\
\hline 10.1 & Valvata cristata Müller & 15 & 7 & 5 & 16 & 10 & 20 \\
\hline 10.5 . & Lymnaea occulta (Jackiewicz) & & & 1 & 1 & 7 & 3 \\
\hline 10.7. & Lymnaea truncatula (Müller) & & 1 & & & & \\
\hline 10.10 & Planorbis planorbis (Linnaeus) & & 1 & & & & 1 \\
\hline 10.14 & Gyraulus riparius (Westerlund) & & & & & 1 & \\
\hline 10.15 & Gyraulus rossmaessleri (Auerswald) & & & & & 1 & \\
\hline 10.16 & Segmentina nitida (Müller) & & & & & 2 & 3 \\
\hline 10.18 & Pisidium pseudosphaerium Schlesch & & & & 1 & & \\
\hline 11.1 & Viviparus contectus (Millet) & 3 & 3 & 3 & 3 & 8 & 14 \\
\hline 11.2 & Valvata piscinalis (Müller) & 248 & 440 & 230 & 1250 & 1000 & 1000 \\
\hline 11.3 & Bithynia tentaculata (Linnaeus) & 20 & 24 & 17 & 87 & 213 & 101 \\
\hline 11.3 & Bithynia tentaculata (Linnaeus) - operculata & 240 & 370 & 201 & 192 & 1000 & 300 \\
\hline 11.5 & Lymnaea stagnalis (Linnaeus) & 13 & 13 & 9 & 12 & 19 & 35 \\
\hline 11.9 & Planorbarius corneus (Linnaeus) & 1 & 6 & 4 & 2 & 4 & 21 \\
\hline 11.10 & Marstoniopsis scholtzi (Schmidt) & & & & 1 & & 12 \\
\hline 11.11 & Anisus vortex (Linnaeus) & & & 1 & 1 & 1 & 9 \\
\hline 11.13 & Bathyomphalus contortus (Linnaeus) & & 1 & & & & 2 \\
\hline 11.14 & Gyraulus albus (Müller) & 5 & 7 & 8 & 36 & 23 & 38 \\
\hline 11.15 & Gyraulus laevis (Alder) & & & & & 21 & \\
\hline 11.16 & Gyraulus acronicus (Férussac) & & & & 1 & 4 & \\
\hline 11.17 & Armiger crista Linnaeus & 1 & 1 & 1 & 7 & 20 & 20 \\
\hline 11.19 & Acroloxus lacustris (Linnaeus) & 1 & 2 & & 3 & 10 & 1 \\
\hline 11.20 & Sphaerium corneum (Linnaeus) & & & 1 & 1 & 1 & \\
\hline 11.21 & Pisidium henslowanum (Sheppard) & 10 & 15 & 15 & 75 & 300 & 110 \\
\hline 11.22 & Pisidium milium Held & & & & & 1 & 1 \\
\hline 11.23 & Pisidium subtruncatum Malm & & & & & 2 & 3 \\
\hline 11.24 & Pisidium pulchellum Jenyns & & & & & & 1 \\
\hline 11.26 & Pisidium casertanum (Poli) & 5 & 5 & 8 & & 20 & 30 \\
\hline 11.26 & Pisidium casertanum ponderosa (Stelfox) & 10 & 15 & 20 & 36 & 35 & 100 \\
\hline 11.28 & Pisidium moitessierianum Paladilhe & & & & & & 1 \\
\hline 12.10 & Ancylus fluviatilis Müller & 1 & & & & & \\
\hline 12.11 & Unio sp. & 18 & 15 & 10 & 10 & 10 & 1 \\
\hline 12.21 & Pisidium amnicum (Müller) & & & 4 & & & \\
\hline 12.19 & Sphaerium rivicola Lamarck & & & & & & 3 \\
\hline 12.24 & Pisidium nitidum Jenyns & 2 & & & & & \\
\hline & Total & 682 & 1127 & 639 & 1738 & 2720 & 1831 \\
\hline
\end{tabular}




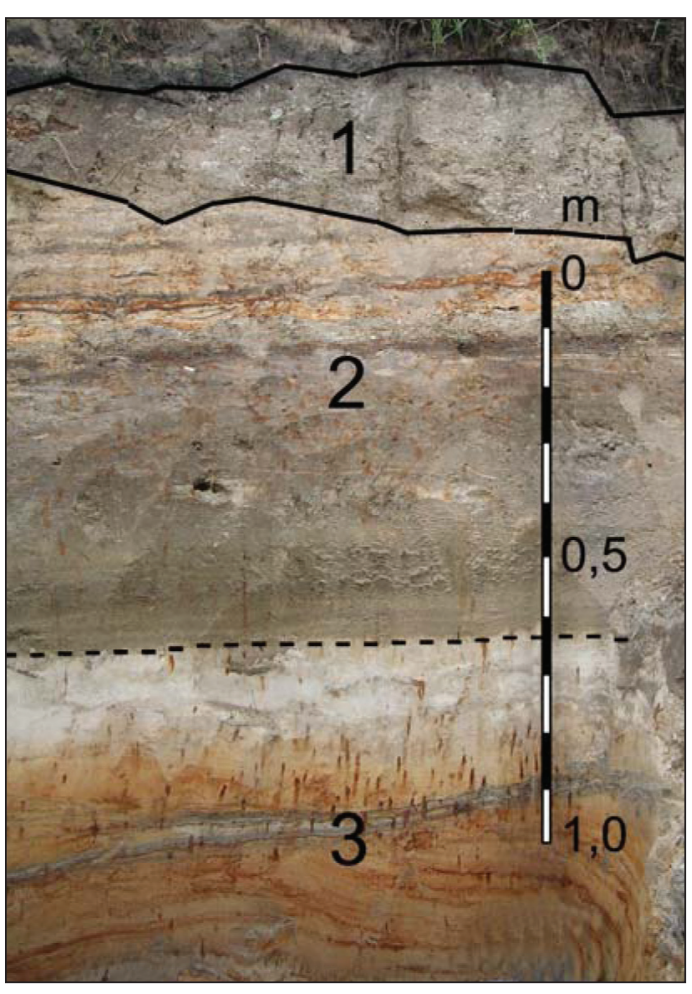

Fig. 7. Section of 3-m high flood-plain of the Pelesa River (Dubičiai-4 site of mollusc fauna): 1 - calcareous tufa, 2 - flood-plain facies, 3 - near-channel alluvium facies 7 pav. Dubičių-4 pjūvis

Conditions under which the freshwater calcareous deposits were forming on a 3-m flood-plain of the Pelesa River differed with the site. The site of Dubičiai-4, situated at a distance of only $100 \mathrm{~m}$ from Dubičiai- 1 but on the right bank of the river, is notable for calcareous tufa deposits. They occur as a lens in the upper part of the flood-plain facies of alluvium (Fig. 7). The pressure of spring water was rather strong and caused formation of a lower erosional boundary. The calcareous tufa contains an admixture of coarse sand with gravel, which seems to have come during the flood periods. This assumption is confirmed by presence of rheophilous molluscs in the calcareous tufa (ecological group 12, see Table 2). Their share, however, in the total composition of freshwater mollusc shells was too small, just several hundredths of a percent. The key role (about $82 \%$ ) was played by two euryecological

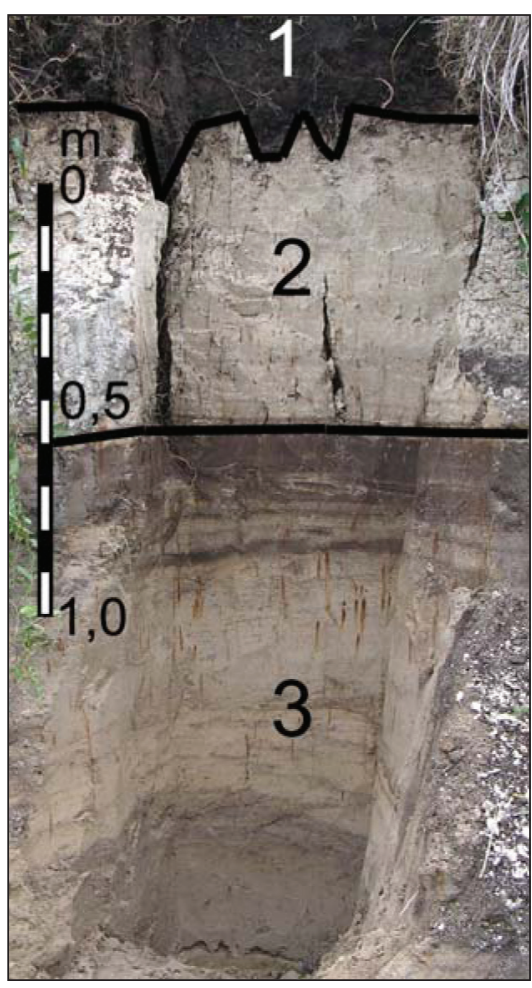

Fig. 8. Section of 2.5-m high flood-plain of the Pelesa River (Dubiciai-2 site of mollusc fauna): 1 - peat, 2 - meadow marl ("gazha"), 3 - flood-plain alluvium facies 8 pav. Dubičių-2 pjūvis

species - Valvata piscinalis (Müller) and Bithynia tentaculata (Linnaeus). They are adapted to live in both flowing and calm water. The terrestrial molluscs of Dubičiai- 4 are very rare; this indicates the position of the former spring far away from higher terraces and valley slope. The lacustrine species played the key role among the Dubičiai-4 malacofauna. Viviparus contectus (Millet) is a typical representative of the lacustrine group of molluscs. This species usually populates the overgrown silting water bodies with calm water. Such conditions are observed in oxbow lakes, meadow water bodies, peatbogs and bogs.

Freshwater calcareous deposits of Dubičiai-2 site occur also in the upper part of the flood-plain beds covered by thin peat. The flood-plain is in a shape of a $2.5-\mathrm{m}$ high bar sidling the 3-m high flood-plain level. Fine and pelitomorphous cal-

Table 4. Mollusc fauna from Dubičiai 2 section deposits

4 lentelè. Moliuskai iš Dubičių 2 pjūvio nuosèdų

\begin{tabular}{|c|c|c|c|c|c|c|c|c|}
\hline & \multirow{2}{*}{ Taxa } & \multicolumn{7}{|c|}{ Sample } \\
\hline & & 1 & 2 & 4 & 5 & 6 & 7 & 8 \\
\hline 9.9 & Succinea putris (Linnaeus) & & & & & 1 & & \\
\hline 10.15 & Gyraulus rossmaessleri (Auerswald) & & 4 & 11 & 1 & 3 & & 2 \\
\hline 11.2 & Valvata piscinalis (Müller) & 132 & 195 & 80 & 68 & 56 & 57 & 32 \\
\hline 11.3 & Bithynia tentaculata (Linnaeus) & 3 & 2 & & 1 & & & \\
\hline 11.3 & Bithynia tentaculata (Linnaeus) - operculata & 41 & 4 & 11 & 4 & 2 & 6 & 20 \\
\hline 11.17 & Armiger crista Linnaeus & & & & & & 2 & 1 \\
\hline 11.21 & Pisidium henslowanum (Sheppard) & & 1 & 1 & & 1 & 3 & 4 \\
\hline 11.26 & Pisidium casertanum ponderosa (Stelfox) & & 1 & & & & & \\
\hline & Total & 176 & 207 & 103 & 74 & 63 & 68 & 59 \\
\hline
\end{tabular}


Table 5. Malacofauna of Late Glacial and Holocene freshwater calcareous deposits in Lithuania

5 lentelè. Vèlyvojo ledynmečio ir holoceno gèlavandeniai moliuskai (Lietuva)

\begin{tabular}{|c|c|c|c|c|c|}
\hline $\begin{array}{l}\text { Genetic } \\
\text { type of } \\
\text { deposits }\end{array}$ & $\begin{array}{l}\text { Genetic } \\
\text { subtype of } \\
\text { deposits }\end{array}$ & $\begin{array}{l}\text { Group of } \\
\text { facies }\end{array}$ & Facies & Typical species of molluscs & Sections \\
\hline \multirow{3}{*}{$\begin{array}{l}\text { Chemo- } \\
\text { genous }\end{array}$} & \multirow{3}{*}{$\begin{array}{c}\text { Spring } \\
\text { (fountain) }\end{array}$} & Lacustrine & $\begin{array}{c}\text { Freshwater lime ("gazha", } \\
\text { meadow marl) }\end{array}$ & $\begin{array}{c}\text { Pisidium obtusale, P. obtusale lapponicum, Valvata pis- } \\
\text { cinalis alpestris, Lymnaea stagnalis, Pisidium milium, } \\
\text { P. lilljeborgi, P. cf. casertanum, P. nitidum }\end{array}$ & $\begin{array}{c}\text { Mūšos Tyrelis, } \\
\text { Pabaliai }\end{array}$ \\
\hline & & $\begin{array}{l}\text { Valley- } \\
\text { hollow- } \\
\text { peatbog }\end{array}$ & $\begin{array}{l}\text { Calcareous peat and calcare- } \\
\text { ous tufa (peat tufa, "mada") } \\
\text { of low bogs at the bottom } \\
\text { of river valleys, hollows, with } \\
\text { interlayers and lenses of pure } \\
\text { freshwater lime }\end{array}$ & $\begin{array}{c}\text { Pupilla muscorum, Vallonia costata, Vallonia pulchella, } \\
\text { Cochlicopa lubrica, Carychium minimum, Valvata } \\
\text { cristata, Viviparus contectus, Valvata piscinalis, Bithy- } \\
\text { nia tentaculata, Lymnaea stagnalis, Pisidium caserta- } \\
\text { num ponderosa, Unio sp., Sphaerium rivicola }\end{array}$ & $\begin{array}{l}\text { Dubičiai 1, } \\
\text { Dubičiai 2, } \\
\text { Dubičiai } 4\end{array}$ \\
\hline & & Terrestrial & $\begin{array}{c}\text { Calcareous tufa of slopes } \\
\text { and their feet }\end{array}$ & $\begin{array}{c}\text { Acicula polita, Discus ruderatus, Perforatella biden- } \\
\text { tata, Vallonia costata, Vallonia pulchella, Nesovitrea } \\
\text { hammonis, Carychium tridentatum, Vertigo angustior, } \\
\text { Carychium minimum, Pisidium personatum }\end{array}$ & Dūkštos \\
\hline
\end{tabular}

careous deposits are characteristic of the site (Fig. 8), indicating the formation of deposits under calm sedimentation conditions. The mollusc fauna of this site is scantier than that of Dubičiai-4 and is composed mainly of the same two euryecological species Valvata piscinalis (Müller) and Bithynia tentaculata (Linnaeus) (Table 4 ).

Calcareous deposits of the lacustrine group of the facies occur in water bodies in which $\mathrm{CaCO}_{3}$ accumulation is related to a high position of carbonaceous springs. Formation of these deposits takes place in the near-shore zone or in the marginal parts of underwater slopes of lakes. Deposits of this facies are represented by freshwater lime varieties ("gazha",

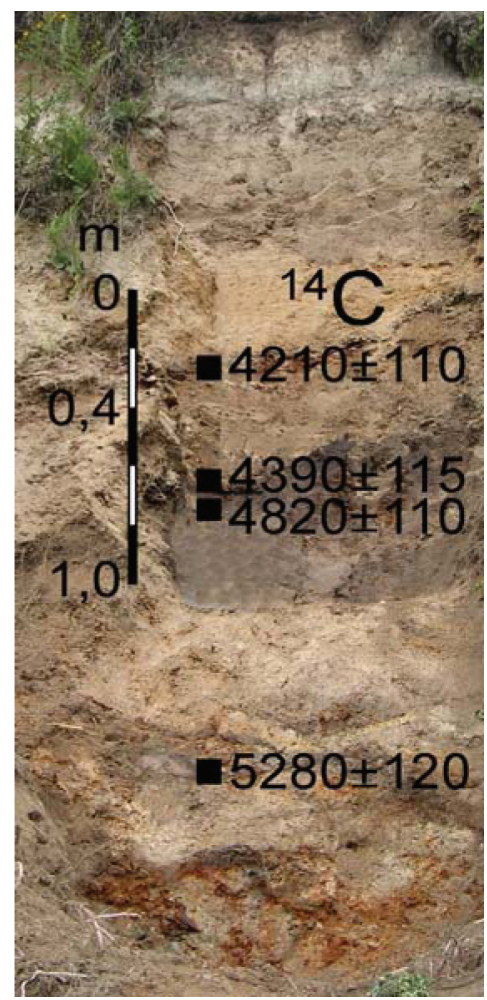

Fig. 9. Dūkštos calcareous tufa of the Dūkštos River valley 9 pav. Dukštos pjūvio karbonatiniai tufai meadow marl) in the shape of lenses and interlayers under the peat bed (Mūšos Tyrelis, Pabaliai sections) or surrounded by sand-aleurite deposits. The mollusc fauna reflects the lake conditions under which the deposits were forming and lacustrine species were developing together with euryecological freshwater molluscs. Accumulation of freshwater lime could start also during the Late Glacial. In this case, fauna contains a cold water association of species headed by Pisidium obtusale lapponicum Clessin. There are almost no rheophilous molluscs in the lacustrine, and representatives of terrestrial fauna are very rare.

Calcareous deposits of the valley-hollow-peatbog group of facies are formed at the bottom of linear depressions of relief with impeded outflow of water. Here, the conditions favour bogging and formation of peat-bogs of eutrophic type.A constant seepage of shallow groundwater proceeds from the bottom across a newly-formed peat bed so that water reaches the surface or spreads between the peat strata and enriches them with carbonates. Thus, peat-tufa is formed. In case of a significant inflow of water to the bottom, shallow water bodies such as puddles are formed, sometimes disappearing or again appearing in new places. In this case, the volume of freshwater deposits in the section prevails over the volume of peat. Polish investigators call such calcareous freshwater deposits "mada". Complex and often changing conditions of the formation of deposits are reflected in malacofauna. Peat tufa, or "mada", is notable for a rich fauna of molluscs consisting of freshwater, mainly lacustrine, species with the participation of rheophilous (stream) molluscs, as well as species of ephemeral disappearing water bodies. The "mada" can be abundant in shells of terrestrial molluscs entering a water body from its steep slopes. The mollusc fauna of Dubičiai-1 presents the most typical case of "mada".

The terrestrial group of facies is related to the calcareous deposits formed under overland conditions on the slopes at the feet of hills as well as in gullies, ravines and hollows. The deposits are notable for a high content of $\mathrm{CaCO}_{3}$ (to 99\%) and represented by solid, grainy, loose and sometimes lumpy 
formations. Their thickness, type of occurrence and structural peculiarities depend on the place of the spring, slope steepness, the state of vegetation cover, water discharge from a spring, and its mineral content. Depending on the admixture of psephits, red-brown iron oxides, plant remains, the colour of deposits can range from white and yellowish to yellowish-grey, grey, rust brown and dark grey (Fig. 9). The mollusc fauna of calcareous tufa is represented almost entirely by terrestrial species, which enable to identify the environment conditions (temperature, air humidity and vegetation character) and to judge about the time the deposits have been forming. An example of malacofauna characterising valley slope calcareous deposit facies is the fauna in the Dükštos section (Sanko et al., 2008).

\section{DISCUSSION AND CONCLUSIONS}

Malacofauna in freshwater calcareous deposits of three types has been investigated. The molluscs sampled from freshwater calcareous deposits (the Dükšta section) formed in the springs inhabited this environment from the Holocene climate optimum - the end of the Atlantic period to the present time. The calcareous tufa is found to contain remains of terrestrial molluscs which sometimes prevail over the freshwater mollusc species. The terrestrial complex of malacofauna consists of forest (11 taxa), open area ( 3 taxa) and mesophil (21 taxa) species. The malacofauna consists of such thermophils as Acicula polita (Hartman), Acanthinula aceleata (Müller), Aegopinella cf. pura (Alder), Bulgaria cana (Held) and Discus cf. rotundatus (Müller), as well as the migrant Caryshium tridentatum (Risso) from South Europe and Vertigo moulinsiana (Dupuy) from West Europe.

The malacofauna of Mūšos Tyrelis consists of 22 taxa, with lacustrine species prevailing. There are also quite a few species of ephemeral and vanishing water bodies detected. The most important position falls to the Late Glacial species of Pisidium obtusale lapponicum Clessin which inhabited cold water and had not passed to the Holocene fauna; next to be mentioned is the rather cold water dweller P. lilljeborgi Clessin which had passed to the Holocene fauna. The formation of sapropel took place already in the Late (Late Nemunas) Glacial, while the accumulation of gyttja and peat proceeded in the Early Holocene.

Although this malacofauna is dominated by lacustrine species, it contains also fluvial species, such as Ancylus fliuviatilis (Müller), Unio sp., Pisidium amnicum (Müller), and Sphaerium rivicola Lamarck (the Dubičiai section).

\section{ACKNOWLEDGEMENTS}

We would like to express our gratitude to late Prof. Algirdas Gaigalas (1933-2009); under his guidance, field investigations were carried out on mollusc fauna in sections of freshwater calcareous deposits in Lithuania. This study was financed by the Research Council of Lithuania (No. LEK-10005).

\section{References}

1. Bartoš T. D. 1976. Geologiya i resursy prienovodnykh izviestkovykh otlozheniy golocena. Srednyaya polosa Evropeyskoy chasti SSSR [Geology and resources of freshwater calcareous deposits in the middle latitudes of the European part of the USSR]. Riga: Zinatne.

2. Vaitekunas P. P., Motuzas V. M., Jasas A. 1970. O malakofaune drevneozernykh otlozheniy r. Uli i genezise vmeschayushchey peschianoy tolshchi [About the malacofauna of palaeo-lacustrine deposits of the Üla River and sand bed genesis]. Geografija ir geologija. VII: 153-164.

3. Danilans I. J. 1957. Golotsenovye priesnovodnye izvestkovyje otlozheniya Latvii. [Holocene freshwater calcareous deposits of Latvia. Riga]. Рига: Изд-во АН Латв. ССР, 152 c.

4. Damušyte, A. 2009. Late glacial and holocene subfossil mollusc shells on the Lithuanian Baltic Sea coast. Baltica 22(2): 111-122.

5. Gaigalas A., Sanko A., Pazdur A., Pawlyta J., Michczyński A., Budenaite S. 2007. Buried oaks and malacofauna of Holocene oxbow lake sediments in the Valakupiai section, Lithuania. Geologija 58: 34-48.

6. Sanko A., Gaigalas A. 2008. Allerod deposits at Zervynos on the Üla River: geology, geochronology and malacofauna. Geologija 1(61): 49-57.

7. Sanko A., Gaigalas A., Rudnickaitė E., Melešytė M. 2008. Holocene malacofauna in calcareous deposits of Dūkštos site near Maišiagala in Lithuania. Geologija 50(4(64)): 290-298.

Aleksandr Sanko, Julius Vainorius, Monika Melešytė

\section{LIETUVOS VÉLYVOJO PLEISTOCENO IR HOLOCENO GÉLAVANDENIŲ KARBONATINIŲ NUOGULŲ MALAKOFAUNA}

\section{Santrauka}

Šiame straipsnyje apibendrinami Lietuvos gèlavandenių karbonatinių nuogulų malakofaunos tyrimai. Moliuskų liekanos buvo išanalizuotos pagrindiniuose gèlavandenių karbonatinių nuogulų genetiniuose tipuose: 1) šaltinių, 2) ežerų ir 3) aliuvinio. Kiekvieno tipo gèlavandenès karbonatinès nuogulos gana ryškiai skiriasi tiek slūgsojimu pagrindinių reljefo formų atžvilgiu, tiek ir nuogulų sudètimi bei moliuskų liekanų ịvairove. Mūšos tyrelio malakofauna tirta eksploatuojamo durpių karjero prakasoje. Mėginiai imti iš užklotų durpėmis ežerinių pelkès guolio nuosèdų. Mūšos tyrelio malakofauną sudaro 22 taksonai. Svarbiausią vietą užima vèlyvojo glacialo rūšis Pisidium obtusale lapponicum Clessin, gyvenusi šaltame vandenyje, nepereinanti ị holoceno fauną, šaltoko vandens gyventoja $P$. lilljeborgi Clessin, pereinanti į holoceno fauną, tipiška holoceno laikotarpio malakofaunos rūšis - Bithynia tentaculata (Linnaeus) bei tranzitinè rūšis Lymnaea peregra (Müller). Pastaroji gali būti tiek vèlyvojo pleistoceno, tiek ir holoceno faunoje. Taigi sapropelio formavimasis (remiantis aukščiau nurodyta malakofauna) vyko dar vèlyvuoju (vèlyvasis Nemunas) ledynmečiu. Gitijos ir durpių dalis kaupėsi (sprendžiant pagal tyrinètą malakofauną) ankstyvajame holocene. 